\title{
THE RELATIONSHIP BETWEEN ON TIME CLEARANCE AND ON TIME DELIVERY IN PT. XYZ PERIOD FEBRUARY - JULY 2017
}

\author{
Intan Baiduri ${ }^{1}$ \\ 1. STMT Trisakti \\ $\triangle$ corresponding author: Baidurintan08@gmail.com
}

\begin{abstract}
PT. XYZ is trading company and subsidiary of the big one trading company in Japan. PT. XYZ is engaged in construction cold storage and export import. The problem of this journal is to find out the relationship between on time clearance and on time delivery. To analyst the data, the author used simple linear regression analysis, correlation coefficient analysis, and hypothesis test. The result of analysis showed the equation $Y=5,17+1 X$ which means that the number of on time clearance and on tie delivery is positive with 1 . From the correlation coefficient formula, the result is $r=0,8402$. The analysis also found out that the determinant coefficient is $70,59 \%$ whereas the effect of other factors is $29,41 \%$. Based on hypothesis testing the results is $3,09>2,13$ or $t_{\text {count }}>t_{\text {table }}$ which means $\mathrm{Ho}$ rejected and $\mathrm{Ha}$ accepted. In the other words, there are positive relationship between the number on time clearance and on time delivery.

Keywords : on time clearance, on time delivery
\end{abstract}

\section{Introduction}

Related to government policy as though in UU No. 17 Tahun 2006 about customs, be known Convenience Import for Export Purpose policy (Kemudahan Import Tujuan Eksport) import goods are processed become finish goods before duty and tax paid off by importer. Port area not wide enough to accommodate activity, related government policy to support increasing import. This is basic consideration for government to decide the industrial zone outside of port. Bonded zone based on D.A Lasse (2014 : 277 ) is temporary hoard (TPS) which is under customs control.

Convenience import for export purpose, encourage investors to invest in Indonesia. Industrial activity in Indonesia is increase go forward. So many corporation want to build manufactures company in Indonesia. The purpose is to export the goods after the goods become finish goods.

PT. XYZ is trading company and subsidiary of the big one trading company in Japan. PT. XYZ is engaged in construction cold storage and export import. Commodity import of PT. XYZ is automobiles, food, plastics resin and chemicals. 
PT. XYZ as once of company which continue to rise and grow, PT. $\mathrm{XYZ}$ always want to provide best service with international standard. PT. $\mathrm{XYZ}$ is the one of supplier plastics resin for the big manufactures company which produced piano and applying just in time delivery for receiving activity. Plastics resin imported from Japan to Jakarta using sea transportation mode and need 14 days voyage to arrive in Jakarta. With increasing collaboration in this time, customer want to every delivery activity should appropriate with schedule in order to support production activity still running well.

In order to delivery activity appropriate with schedule. So, need good cooperation and good communication between supplier, exporter, importer, and customer. To push inventory cost, PT. XYZ order material periodically to exporter with shipping schedule which has been specified.

In the other hand, shipping schedule which arrange by exporter does not appropriate with the shipping schedule that already request before. It's will make availability of material not appropriate with schedule. If stock out it's happen, it will make company lose out because the impact is very high. First, company will lose the chance to sell the material. Second, company will lose trust from customer and company will have bad reputation because can't fill customer request and customer needed. Third, If stock out it's happen, production activity in customer company will stop line and can't continue production activity, customer will have lose out during production activity stop. Willem Siahaya (2013: 121).

Then, exporter is late to send original shipping document. It makes customs clearance process also late and finish not appropriate with target, because should wait original shipping document arrived. As a result, it makes the material late inbound to warehouse and inbound schedule not appropriate with target. So that, delivery process to customer late. Unpredictable order and some of material does not mentioned in the forecast also make obstacles. It will makes PT. XYZ should order the material first to exporter because PT. XYZ don't have any stock for that material. 
Finally, delivery schedule for that material can't arrange appropriate with the schedule before, because should wait until the vessel arrive to Jakarta and waiting customs clearance finish. Delivery schedule from customer is very unpredictable and they are reschedule delivery date. It makes material inventory fluctuating and should advance shipping schedule. So, the material delivery schedule will appropriate with customer request.

Based on this background, the related topics in this journal can be identified as follows:

a. The shipping schedule arranged by the exporter does not appropriate with the request

b. Exporter late to send shipping document

c. Process customs clearance finish does not appropriate with target

d. Unpredictable material order and material order does not mention in forecast

e. Unpredictable delivery schedule

\section{Method}

\section{a. Simple Linear Regression Analysis}

Regression analysis used is in the form of simple linear regression based on functional or causal relationship between independent variable and dependent variable. The general equation of simple linear regression as follows, Sugiyono $(2015: 261)$ :

$$
\hat{Y}=a+b X
$$

Sugiyono (2015 : 262) a dan b can be searched by the following formula:

$$
\begin{aligned}
a= & \frac{(\Sigma \mathrm{Y})\left(\Sigma \mathrm{X}^{2}\right)-(\Sigma \mathrm{X})(\Sigma \mathrm{XY})}{n \Sigma \mathrm{X}^{2}-(\Sigma \mathrm{X})^{2}} \text { dan } \quad b=\frac{n \Sigma \mathrm{XY}-(\Sigma \mathrm{X})(\Sigma \mathrm{Y})}{n \Sigma \mathrm{X}^{2}-(\Sigma \mathrm{X})^{2}} \\
& \text { Details : } \\
& \hat{Y}=\text { Variable dependent } \\
& X=\text { Variable independent } \\
& a=\text { Constants (fixed number }) \\
b & =\text { Coefficient regression }
\end{aligned}
$$




$$
n=\text { Number of sampel }
$$

\section{b. Coefficient Correlation Analysis}

Sugiyono $(2015: 228)$ said that this correlation technique is used to find the relationship and prove hypothesis relation of two variables when the data of the two variables in the form of interval or ratio, and data source of two variables or more is the same.

$$
\boldsymbol{r}_{x y}=\frac{n \sum \mathrm{XY}-\left(\sum \mathrm{X}\right)\left(\sum \mathrm{Y}\right)}{\sqrt{n \sum \mathrm{X}^{2}-\left(\sum X\right)^{2}} \sqrt{n \sum \mathrm{Y}^{2}-\left(\sum Y\right)^{2}}}
$$

Details : $r_{x y}=$ Coefficient correlation between variable $x$ and $\mathrm{y}$

Sugiyono ( $2015: 231$ ) said to find the level of on time clearance (Variable X) with on time clearance (Variable Y) at PT. XYZ used the following criteria:

Table 1. Interpretation of Correlation Coefficients

\begin{tabular}{|c|c|}
\hline Coefficient Interval & Relationship Level \\
\hline $0,00-0,199$ & Very Low \\
\hline $0,20-0,399$ & Low \\
\hline $0,40-0,599$ & Medium \\
\hline $0,60-0,799$ & Strong \\
\hline $0,80-1,000$ & Very Strong \\
\hline \multicolumn{2}{|c|}{ Sources : (Sugiyono. $2015: 231)$} \\
\hline
\end{tabular}

Correlation coefficient is a benchmark to assess the proximity of the influence of variable $\mathrm{X}$ and variable $\mathrm{Y}$. The value of this correlation coefficient of at least -1 and most +1 , if made persuasion can be expressed as follows:

$$
-1 \leq \mathrm{r}+\leq 1
$$

Meaning:

1) If $r=-1$ or close to -1 , it means that there is a perfect or very strong negative effect between variable $\mathrm{X}$ and variable $\mathrm{Y}$.

2) If $r=+1$ or close to +1 , it means that there is perfect or very strong positive effect between variable $\mathrm{X}$ with variable $\mathrm{Y}$.

3) If $r=0$ or near 0 , then there is no effect or very weak influence between variable $\mathrm{X}$ with variable $\mathrm{Y}$. 


\section{c. Coefficient of Determination Analysis}

If the correlation coefficient is squared, it will be the determinant coefficient $(\mathrm{KP})$ or the coefficient of determination, which means the cause of change in the variable $\mathrm{Y}$ coming from variable $\mathrm{X}$, equal to the square of the correlation coefficient. This determinant coefficient describes the magnitude of the effect of the value of a variable (variable $\mathrm{X}$ ) on the rise or fall (variation) value of other variables (variable Y). Iqbal Hasan (2012 : 236) said coefficient formula as follows : Kp $=\mathbf{r}^{\mathbf{2}} \mathbf{x}$ $100 \%$

Details : $\quad \mathrm{Kp}=$ Coefficient of Determination value $\quad \mathrm{r}^{2}=$ Correlation coefficient

\section{d. Hypothesis Test}

Hypothesis testing is a procedure that allows decisions to be made, that is reject or accept alternative hypothesis $(\mathrm{Ha})$ presented in the previous section. Hypothesis testing (one-tailed test) with right tail test "Right tail test is used when the null hypothesis $(\mathrm{Ho})$ reads" smaller or equal to $(\leq)$ "and the alternate hypothesis (Ha) reads" bigger (>) ". Sentences smaller or equal to synonyms with the word "bigest" with comparing $t_{\text {count }}$ and tTable said Sugiyono (2015:102).

Sugiyono $(2015: 230)$ said to find value of $t_{\text {count }}$ to test the hypothesis used the following formula : $\quad t=\frac{r \sqrt{n-2}}{\sqrt{1-r^{2}}}$

Then, to find $\mathrm{t}_{\text {Table }} \mathrm{used} \mathrm{t}$ distribution table as follows : $\boldsymbol{\alpha}=\mathbf{0 , 0 5} ; \mathbf{d k}=$ n-2

Details : $t=\mathrm{t}_{\text {count }}$ which is then consulted with $\mathrm{t}$ table $r=$ Correlation coefficient

Meaning:

If $t_{\text {count }}>t$ table, then $\mathrm{Ha}$ accepted and Ho rejected, meaning there is influence of variable $\mathrm{X}$ with variable $\mathrm{Y}$.

If $t_{\text {count }}<t_{\text {table, }}$, then Ha rejected and Ho accepted, meaning there is no influence of variable $\mathrm{X}$ with variable $\mathrm{Y}$. It can be described as follows

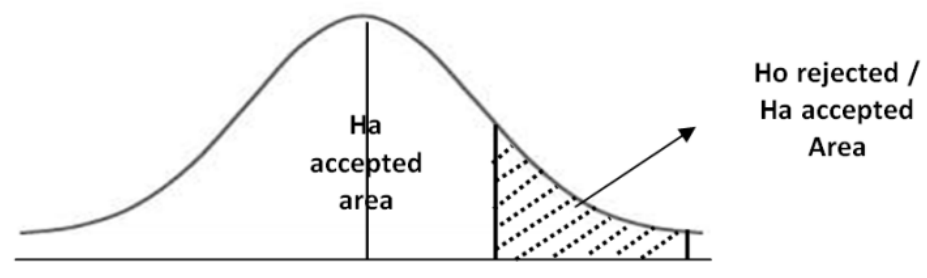




\section{Result and Discussion}

\section{Analysis of on time clearance in PT. XYZ period February - July} 2017

In this journal, authors take data on time clearance and on time delivery in PT. XYZ period February - July 2017. In the below side is number of on time clearance data around 6 month.

Table 2. On time clearance in PT. XYZ period February - July 2017

\begin{tabular}{|c|c|c|c|}
\hline Month & $\begin{array}{c}\text { On time clearance } \\
(\mathrm{X})\end{array}$ & $\begin{array}{c}\text { Increasing and Decreasing } \\
\text { On time clearance }\end{array}$ & Presentation \\
\hline \hline Feb-17 & 3 & - & - \\
\hline Mar-17 & 3 & 0 & $0 \%$ \\
\hline Apr-17 & 3 & 0 & $0 \%$ \\
\hline Mei-17 & 2 & $(1)$ & $(33 \%)$ \\
\hline Jun-17 & 3 & 1 & $50 \%$ \\
\hline Jul-17 & 4 & 1 & $33 \%$ \\
\hline
\end{tabular}

Sources : PT. XYZ (processed by author)

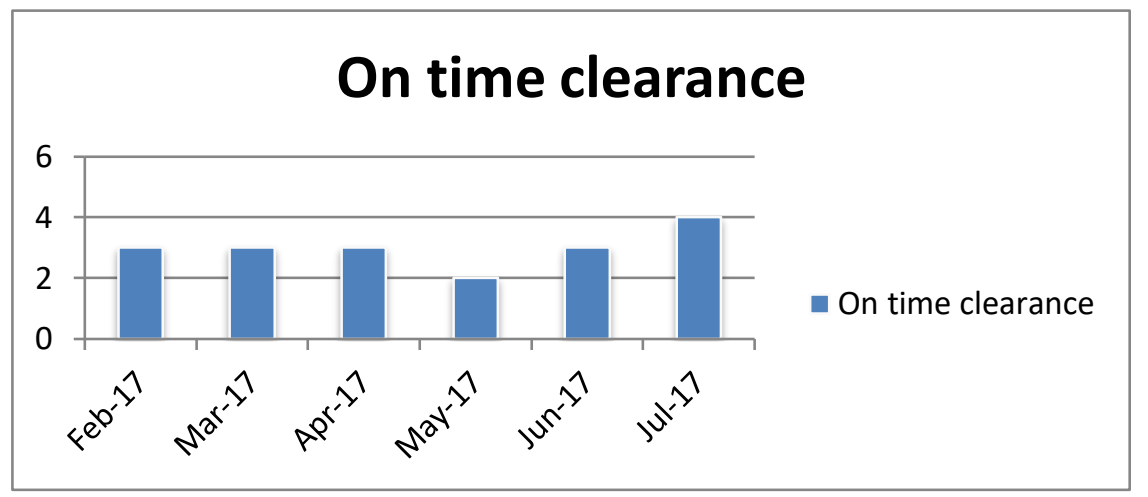

Diagram 1. On time clearance in PT. XYZ period February - July 2017 Sources : PT. XYZ (processed by author)

1. On time clearance in February 2017 is 3. In this month can't be calculated increase or decrease because it is the base month for comparison next month.

2. Comparison between February and March 2017 as follows :

$3-3=0$

$$
\frac{0}{3} \times 100 \%=0 \%
$$

From analysis above it means that on time clearance on March 2017 increasing become 0 or $0 \%$ from February 2017. The increasing number of on time clearance because there is no delay customs 
clearance process. Exporter arrange shipping schedule appropriate with request and send original shipping document punctual.

3. Comparison between April and March 2017 as follows :

$3-3=0$

$$
\frac{0}{3} \times 100 \%=0 \%
$$

From analysis above it means that on time clearance on April 2017 increasing become 0 or $0 \%$ from March 2017. The increasing number of on time clearance because total import in April and March is same. Then, there is no delay customs clearance process.

4. Comparison between Mei and April 2017 as follows :

$2-3=-1$

$$
\frac{-1}{3} \times 100 \%=-33 \%
$$

From analysis above it means that on time clearance on Mei 2017 decreasing become -1 or $-33 \%$ from April 2017. The decreasing number of on time clearance because total import in Mei 2017 is decreasing. Based on customer forecast, customers don't have much requirement for the material in this month.

5. Comparison between June and Mei 2017 as follows :

$3-2=1$

$$
\frac{1}{2} \times 100 \%=50 \%
$$

From analysis above it means that on time clearance on June 2017 increasing become 1 or $50 \%$ from Mei 2017. The increasing number of on time clearance because total import in June is Increasing become 5 shipment, which is 3 shipment on time clearance and 2 delay customs clearance process. This matters because there is urgent material requirement from customers and the material is not mentioned on forecast before. So that, PT. XYZ should arrange air shipment to provide customer with small quantity material, so customer can do production process. After that, the remains quantity using sea shipment. Exporter also late to send original shipping document (Sea shipment), it makes customs clearance process delay and finish not appropriate with target.

6. Comparison between July and June 2017 as follows : 


$$
4-3=1 \quad \frac{1}{3} \times 100 \%=33 \%
$$

From analysis above it means that on time clearance on July 2017 increasing become 1 or $33 \%$ from June 2017. The increasing number of on time clearance because total import in July 2017 is increasing. Then, there is no delay customs clearance process.

From analysis above, it means on time clearance on June 2017 that have higher increasing become 1 or $50 \%$. The increasing because total import is increasing then previous month. Material requirement from customers is increasing. On time clearances that have higher decreasing is on Mei 2017. The decreasing become -1 or $-3 \%$, because total import is decreasing then previous month.

Increase and decrease of on time clearance because of some factors as follows :

a. The shipping schedule arranged by the exporter does not appropriate with the request

Shipping schedule which arrange by exporter does not appropriate with request before. It's make estimation for material inbound to warehouse delay and availability of material is small. If delivery to customer delay and customer have stock out, it will make company lose out because the impact is very high. Company will lose the chance to sell the material. After that, company will lose trust from customer and company will have bad reputation because can't to fill customer request and customer needed. Then, If stock out it's happen, production activity in customer company will stop line and can't continue production activity, customer will have lose out during production activity stop.

So that, PT. XYZ should applying strict rules to exporter, for arrange shipping schedule appropriate with the request before. So, customs clearance process and inbound process will appropriate with target and also have enough stock for urgent requirement from customer. 
b. Process customs clearance finish does not appropriate with target Process customs clearance process is late because exporter late to send original shipping document. It makes customs clearance process also late and finish not appropriate with target, because should wait original shipping document arrived.

So that, PT. XYZ should inform exporter to send all original shipping document once available and make sure they are already send original shipping document before vessel arrive to Jakarta. So, PT. XYZ don't need to wait long time for customs clearance process and PT. XYZ don't need to pay more for storage cost in port.

c. Unpredictable material order and material order does not mention in forecast

Unpredictable order and some of material does not mentioned in the forecast also make obstacles. PT. XYZ should confirmation the availability for material in origin country and should arrange air shipment for small quantity of material. It will make shipment cost is higher. Finally, delivery schedule for that material can't arrange appropriate with the schedule before, because should wait until the aircraft arrive to Jakarta and waiting customs clearance finish. Delivery schedule from customer is very unpredictable and they are sometimes reschedule delivery date. It makes material inventory fluctuating.

So that, PT. XYZ should have safety stock for some of material. So, if there is urgent requirement for that material. PT. XYZ don't need to have arrange air shipment and delivery schedule to customer is appropriate with customer request.

\section{Analysis of on time delivery in PT. XYZ period February - July} 2017

In this journal, author take data on time clearance and on time delivery in PT. XYZ period February - July 2017. On time delivery is very important for the company that applying just in time system. It will 
make flow of goods appropriate with schedule production. In the below side is number of on time delivery data around 6 month, that is February - July 2017.

Table 3. On time delivery in PT. XYZ period February - July 2017

\begin{tabular}{|c|c|c|c|}
\hline Month & $\begin{array}{c}\text { On time delivery } \\
(\mathrm{Y})\end{array}$ & $\begin{array}{c}\text { Increasing and } \\
\text { Decreasing } \\
\text { On time delivery }\end{array}$ & Presentation \\
\hline \hline Feb-17 & 8 & - & - \\
\hline Mar-17 & 8 & 0 & $0 \%$ \\
\hline Apr-17 & 9 & 1 & $13 \%$ \\
\hline Mei-17 & 7 & $(2)$ & $14 \%$ \\
\hline Jun-17 & 8 & 1 & $13 \%$ \\
\hline Jul-17 & 9 & 1 & \\
\hline
\end{tabular}

Sources : PT. XYZ (processed by author)

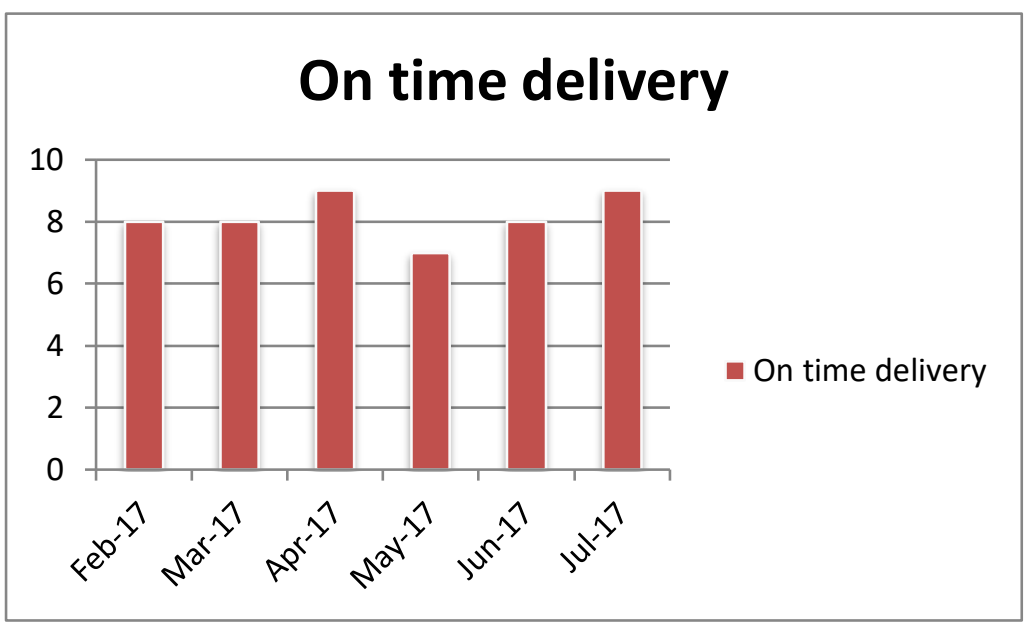

Diagram 2. On time delivery in PT. XYZ period February - July 2017

Sources : PT. XYZ (processed by author)

1. On time delivery in February 2017 is 8. In this month can't be calculated increase or decrease because it is the base month for comparison next month.

2. Comparison between February and March 2017 as follows :

$8-8=0$ $\frac{0}{8} \times 100 \%=0 \%$

From analysis above it means that on time delivery on March 2017 increasing become 0 or $0 \%$ from February 2017. The increasing number of on time delivery because there is no delay customs clearance process. Then PT. XYZ have stock for the 
material in warehouse. So, PT. XYZ can arrange delivery appropriate with delivery schedule from customers.

3. Comparison between April and March 2017 as follows :

$9-8=1$

$$
\frac{1}{8} \times 100 \%=13 \%
$$

From analysis above it means that on time delivery on April 2017 increasing become 1 or 13\% from March 2017. The increasing number of on time delivery because only once delivery delay. Availability material in warehouse is appropriate with schedule before.

4. Comparison between Mei and April 2017 as follows :

$7-9=-2 \quad \frac{-2}{9} 100 \%=-22 \%$

From analysis above it means that on time clearance on Mei 2017 decreasing become -2 or $-22 \%$ from April 2017. The decreasing number of on time delivery because total delivery in Mei 2017 is decreasing. Customers want to delivery material in advance and not appropriate with schedule before.

5. Comparison between June and Mei 2017 as follows :

$8-7=1 \quad \frac{1}{7} \times 100 \%=14 \%$

From analysis above it means that on time delivery on June 2017 increasing become 1 or $14 \%$ from Mei 2017. The increasing number of on time delivery because total delivery in June is Increasing. But there is 2 delay delivery because customers have urgent requirement for once of material that did not mention in forecast. This material is for repairing spare part. The order for this material is very unpredictable.

7. Comparison between July and June 2017 as follows :

$9-8=0 \quad \frac{1}{8} \times 100 \%=13 \%$

From analysis above it means that on time delivery on July 2017 increasing become 0 or $13 \%$ from June 2017. The increasing number of on time delivery because total on time delivery in 
July 2017 is increasing. Availability material in warehouse is appropriate with schedule before. PT. XYZ have stock for the material in warehouse.

From analysis above, it means on time delivery on June 2017 that have higher increasing become 1 or $14 \%$. The increasing because total delivery is increasing then previous month. There is urgent material requirement from customers in June 2017. On time delivery that have higher decreasing is on Mei 2017. The decreasing become -2 or $-22 \%$, because total delivery is decreasing then previous month.

\section{Analysis of the relationship between on time clearance and on time delivery in PT. XYZ Period February - July 2017}

Looking for the relationship between on time clearance and on time delivery. So, the author analyze, there is the relationship between on time clearance and on time delivery. Customs clearance process is have high influence for delivery process to customer. If customs clearance process delay, so delivery process also delay. If it's happen company will lose trust from customer and company will have bad reputation because can't to fill customers request and customer needed.

In the other hand, exporter is arranged shipping schedule does not appropriate with request. It's will make availability of material not appropriate with estimation. Then, exporter is late to send original shipping document. It makes customs clearance process also late and finish not appropriate with target, because should wait original shipping document arrived. As a result, it makes the material late inbound to warehouse and inbound schedule not appropriate with target.

Unpredictable order and the material does not mentioned in the forecast also make obstacles. PT. XYZ should confirmation the availability for material in origin country and should arrange air shipment for small quantity of material. It will make shipment cost is higher. Finally, delivery schedule for that material can't arrange 
appropriate with the schedule before, because should wait until the aircraft arrive to Jakarta and waiting customs clearance finish. Delivery schedule from customer is very unpredictable and they are sometimes reschedule delivery date. It makes material inventory fluctuating.

It can be minimized with applying strict rules to exporter, for arrange shipping schedule appropriate with the request. PT. XYZ should inform exporter to send all original shipping document once available and make sure they are already send original shipping document before vessel arrive to Jakarta. Then, PT. XYZ should have safety stock for some of material. So, if there is urgent requirement for that material. PT. $\mathrm{XYZ}$ don't need to have arrange air shipment and delivery schedule to customer is appropriate with customer request

Table 4. On time clearance and on time delivery in PT. XYZ period February - July 2017

\begin{tabular}{|c|c|c|c|c|c|}
\hline Month & $\begin{array}{c}\text { On time } \\
\text { clearance } \\
(\mathrm{X})\end{array}$ & $\begin{array}{c}\text { On time } \\
\text { delivery } \\
(\mathrm{Y})\end{array}$ & $\mathrm{X}^{2}$ & $\mathrm{Y}^{2}$ & $\mathrm{X}^{*} \mathrm{y}$ \\
\hline \hline Feb-17 & 3 & 8 & 9 & 64 & 24 \\
\hline Mar-17 & 3 & 8 & 9 & 64 & 24 \\
\hline Apr-17 & 3 & 9 & 9 & 81 & 27 \\
\hline Mei-17 & 2 & 7 & 4 & 49 & 14 \\
\hline Jun-17 & 3 & 8 & 9 & 64 & 24 \\
\hline Jul-17 & 4 & 9 & 16 & 81 & 36 \\
\hline Total & 18 & 49 & 56 & 403 & 149 \\
\hline \multicolumn{7}{|c|}{ Sources : PT. XYZ (processed by author) } \\
\end{tabular}

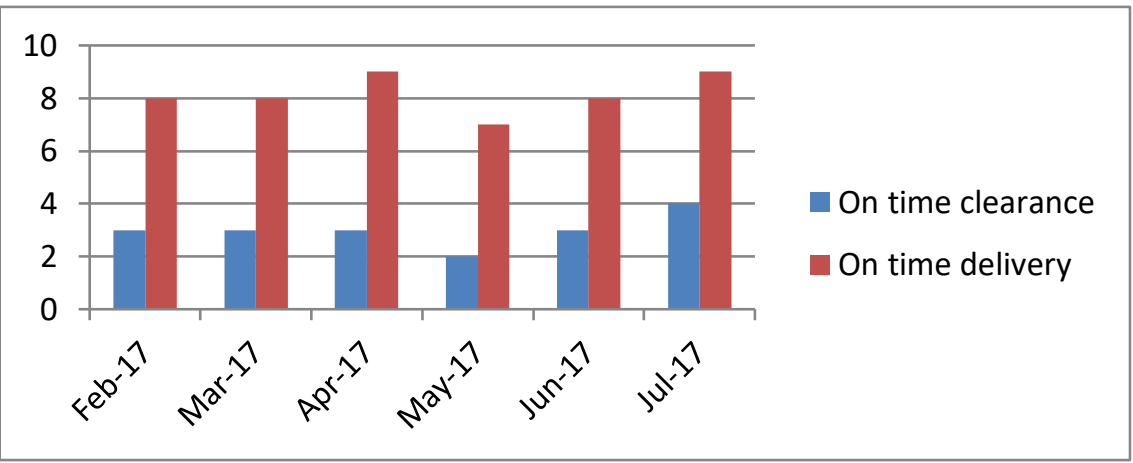

Diagram 3. On time clearance and on time delivery in PT. XYZ period February - July 2017

\section{a. Simple Linear Regression Analysis}

The equation formula of simple regression lines is: $Y=a+b X$ To create a regression line we need to find the values a and $b$, details : 
$\cdot n=6 \cdot \sum \mathrm{X}=18 \quad \cdot \sum \mathrm{X}^{2}=56 \quad \cdot \sum \mathrm{Y}=49 \quad \cdot \sum \mathrm{Y}^{2}$ $=403 \quad \cdot \sum X Y=149$

1) Calculation Formula a

$$
\begin{aligned}
a=\frac{(\Sigma Y)\left(\Sigma X^{2}\right)-}{n \Sigma X^{2}-(\Sigma X)(\Sigma X Y)} \\
=\frac{2744-2684}{336-324}=\frac{(49)(56)-(18)(149)}{(6)(56)-(18)^{2}}
\end{aligned}
$$

2) Calculation Formula $b$

$$
\begin{gathered}
b=\frac{n \Sigma X Y-(\Sigma X)(\Sigma Y)}{n \Sigma X^{2}-(\Sigma X)^{2}}=\frac{(6)(149)-(18)(49)}{(6)(56)-(18)^{2}}=\frac{894-882}{336-324} \\
=\frac{12}{12}=1
\end{gathered}
$$

Regression Equation is :

$$
\dot{Y}=a+b X \quad \dot{Y}=5,17+1 X
$$

Based on the calculation result, got value $\mathrm{a}=5,17$ and $\mathrm{b}=1$, so that regression equation which is $\hat{Y}=5,17,9+1 \mathrm{X}$. From the simple regression equation shows a positive number of 5.17 which means that every increase on time clearance $(\mathrm{X})$ will be followed by an increase in on time delivery (Y) of 1. Similarly vice versa, if on time clearance (X) increases then on time delivery (Y) also increased by 1 then plus (+) value of constant or constant coefficient of 5.17. When depicted in a linear regression equation it will be as follows :

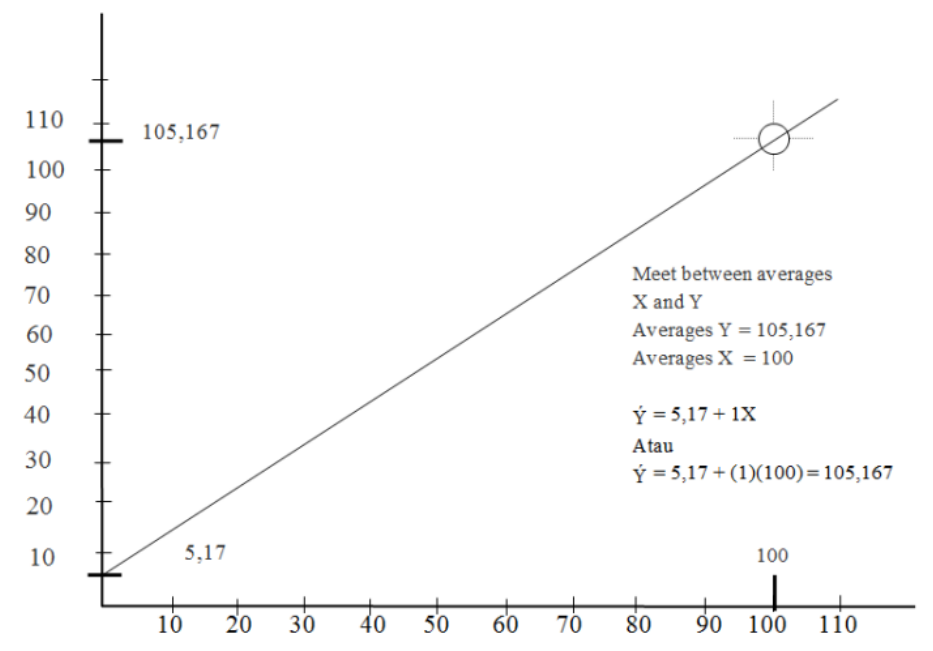

Curve 1. Line Regression Equation 


\section{b. Coefficient Correlation Analysis}

$$
\begin{gathered}
\boldsymbol{r}_{x y}=\frac{n \sum \mathrm{XY}-\left(\sum \mathrm{X}\right)\left(\sum \mathrm{Y}\right)}{\sqrt{n \sum \mathrm{X}^{2}-\left(\sum X\right)^{2}} \sqrt{n \sum \mathrm{Y}^{2}-\left(\sum Y\right)^{2}}}=\frac{6(149)-(18)(49)}{\sqrt{6(56)-(18)^{2}} \cdot \sqrt{6(403)-(49)^{2}}} \\
=\frac{12}{14,2829}=0,8402
\end{gathered}
$$

This means that because $r_{x y}=0,8402$ then total of the above results in accordance with the guidance table to give an interpretation of the correlation coefficient between the values of 0.80 to 1.000 then the relationship between variables $\mathrm{X}$ (on time clearance) and $\mathrm{Y}$ (on time delivery) is very strong.

\section{c. Coefficient of Determination Analysis (KP)}

Used to determine how much contribution or influence of variable $\mathrm{X}$ (on time clearance) to increase - decrease of variable Y (on time delivery), with formula:

$$
\begin{aligned}
\mathrm{r} & =0,8402 \\
\mathrm{KP} & =(\mathrm{r})^{2} \times 100 \%=(0,8402)^{2} \times 100 \%=70,59 \%
\end{aligned}
$$

So, in conclusion that the contribution or on time clearance relationship (variable $\mathrm{X}$ ) on time delivery (variable $\mathrm{Y}$ ) is $70,59 \%$ while the rest of $29,41 \%$ is caused by other factors outside researcher's research, such as activity at port and others.

\section{d. Hypothesis Test}

Here are the steps taken by the researcher to perform hypothesis testing:

The initial hypothesis with $\rho$ is:

1) Ho: $\rho=0$, meaning there is no positive and significant relationship between on time clearance with on time delivery

2) Ha: $\rho>0$, meaning to positive and significant relation between on time clearance with on time delivery

Testing criteria :

1) If $t_{\text {count }}<t_{\text {tabel }}$, maka Ho $=$ accepted 
2) If $t_{\text {count }}>t_{\text {tabel }}$, maka Ho $=$ rejected

To find $t_{\text {count }}$ using the following formula :

$$
t_{\text {count }}=\frac{r \sqrt{n-2}}{\sqrt{1-r^{2}}}=\frac{0,8402 \sqrt{6-2}}{\sqrt{1-0,8402^{2}}}=\frac{1,6802}{0,5423}=3,0984
$$

Based on the distribution $t_{\text {tabel }}$, value of $t_{\text {count }}$ pada $\alpha=5 \%=0,05$

$$
\mathrm{dk}=\mathrm{n}-2 \quad \mathrm{dk}=6-2=4 \quad t_{\text {table }}=2,13
$$

Based on the calculations already obtained, the value of $t_{\text {count }}$ is 3.09 and the value of $t_{\text {tabel }}$ is 2.13 means $t_{\text {count }}>t_{\text {tabel }}$ is 3,09>2,13. Because $t_{\text {count }}$ is larger than $t_{\text {tabel }}$. Then Ho is rejected and $\mathrm{Ha}$ accepted, which means there is a positive relationship between on time clearance $(\mathrm{X})$ with on time delivery $(\mathrm{Y})$ at PT. XYZ. To clarify the above calculation results, we use the following picture distribution curve:

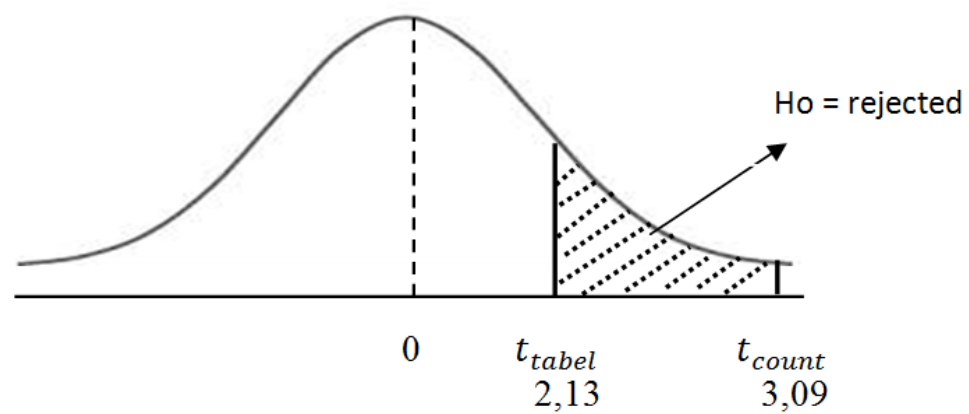

Curve 2. The normal distribution curve of the hypothesis test

From the curve above shows that $t_{\text {count }}$ is in the area of rejection Ho, it can be concluded that $\mathrm{Ho}$ is rejected and $\mathrm{Ha}$ accepted. So it can be concluded that there is a positive relationship between variables $\mathrm{X}$ (on time clearance) to variable Y (on time delivery) proved true.

\section{Conclusion}

Based on the results of the analysis conducted by the researcher it can be concluded that on time clearance on June 2017 that have higher increasing become 1 or $50 \%$. The increasing because total import is increasing then previous month. Material requirement from customers is increasing. On time clearances that have higher decreasing is on Mei 2017. The decreasing become -1 or $-3 \%$, because total import is decreasing then previous month. 
Then, on time delivery on June 2017 that have higher increasing become 1 or $14 \%$. The increasing because total delivery is increasing then previous month. There is urgent material requirement from customers in June 2017. On time delivery that have higher decreasing is on Mei 2017. The decreasing become -2 or $-22 \%$, because total delivery is decreasing then previous month.

Based on the result of analysis showed the equation $\mathrm{Y}=5,17+1 \mathrm{X}$ which means that the number of on time clearance and on time delivery is positive with 1 . From the correlation coefficient formula, the result is $r=$ 0,8402 . The analysis also found out that the determinant coefficient is 70,59 $\%$ whereas the effect of other factors is $29,41 \%$. Based on hypothesis testing the results is $3,09>2,13$ or $t_{\text {count }}>t_{\text {table }}$ which means Ho rejected and $\mathrm{Ha}$ accepted. In the other words, there are positive relationship between the number on time clearance and on time delivery.

PT. XYZ can minimizes the risk with applying strict rules to exporter, for arrange shipping schedule appropriate with the request. PT. XYZ should inform exporter to send all original shipping document once available and make sure they are already send original shipping document. Then, PT. $\mathrm{XYZ}$ should have safety stock for some of material. So, if there is urgent requirement for that material, PT. XYZ don't need to have arrange air shipment and delivery schedule to customer is appropriate with customer request.

\section{Reference}

Back Order Report from customer Febuary - July 2017, PT. XYZ.

D.A. Lasse ; Manajemen Muatan Aktivitas Rantai Pasok di Area Pelabuhan, PT. Raja Grafindo Persada, Jakarta, 2014.

Haryono, Lia Mulia Sari; Analisis Faktor Penyebab Keterlambatan Pengiriman Produk Arnotts ke Alfamart area Jabodetabek dan Banten PT. Intan Utama Logistik Tahun 2015, Jurnal Manajemen Bisnis Transportasi dan Logistik, Vol. 3, No. 1, September, 2016.

Inventory Stock List, PT. XYZ.

Iqbal Hasan ; Pokok Pokok Materi Statistik 2 (Statistik Inferensif), PT.Bumi Aksara, Jakarta, 2012. 
M. Zaini, Bagus Indrawan ; Analisis pengendalin persedian raw material spark plug pada PT. Deso Indonesia, Jurnal Manajemen Bisnis Transportasi dan Logistik, Vol.3, No.1, September, 2016.

Norman Irhamna, Vannesa Aprilian ; Perbaikan Data Dokumen Impor terhadap On Time Clearance pada PT. DHL Forwarding Indonesia, Jurnal Manajemen Bisnis Transportasi dan Logistik , Vol. 2, No.3, Mei, 2016.

Okin Ringan Purba, Jeniffer Wanda; Penyebab Keterlambatan Pengiriman Barang Impor Pada Customer, Jurnal Manajemen Bisnis Transportasi dan Logistik, Vol.1, No.1 September, 2014.

Sugiyono ; Statistika untuk Penelitian, Alfabeta, Bandung, 2015.

Widya Tamodia; Evaluasi Penerapan Sistem pengendalian Intern untuk Persediaan Barang Dagang pada PT. Laris Manis Utama Cabang Manado, Jurnal EMBA, Universitas Sam Ratulangi Manado, Vol.1, No.3, Hal : 20-29, Juni, 2013.

Willem Siahaya ; Supply Chain Management, In Media, Jakarta, 2013.

Yutik Ernawati, Sunarsih ; Sistem Pengendalian Persediaan Model Probabilistik dengan “ Back order Policy” Jurnal Matematika, FMIPA UNDIP, Vol.11, No.2, Hal : 87-93, Agustus, 2008.

Yohanes Nugraha, Mujiono, Dedeng Wahyu Edi; Biaya Logistik dan Kelancaran Pengiriman Barang pada Gerai Buku, Jurnal Manajemen Transportasi dan Logistik (JMTranslog), Vol. 03, No.02, Juli, 2016. 